УДК 343.98

DOI https://doi.org/10.32837/apdp.v0i86.2428

\title{
І.В. Парфило
}

\section{ПРОБЛЕМИ ЗАСТОСУВАННЯ СПЕЦІАЛЬНИХ ЗНАНЬ ПІД ЧАС РОЗСЛІДУВАННЯ ФАЛЬСИФІКАЦІЇ ТА ОБІГУ ФАЛЬСИФІКОВАНИХ ЛІКАРСЬКИХ ЗАСОБІВ}

Постановка проблеми. Результативність встановлення всіх обставин справи, пов'язаних із фальсифікацією й обігом фальсифікованих лікарських засобів, істотно залежить від активного застосування слідчим спеціальних знань, необхідність застосування яких пов'язана як зі специфікою предмета злочинного посягання, так і із залишеними на місці події слідами. Наведене зумовлює виникнення особливостей під час виявлення, фіксації та вилучення слідів, проведення судових експертиз у процесі розслідування фальсифікації й обігу фальсифікованих лікарських засобів. Такі особливості полягають передусім у вузькоспрямованій специфіці самої злочинної діяльності, що впливає як на форму застосування спеціальних знань, так і на варіативність переліку питань, що потребують вирішення, залежно від способу фальсифікації, наявності та виду негативних наслідків та інших елементів криміналістичної характеристики.

Вбачається, що неврахування слідчими й іншими учасниками кримінального провадження зазначених особливостей призводить до втрати доказової інформації, необхідності повторення проведення слідчих (розшукових) дій, сприяє появі проблемних слідчих ситуацій. У зв'язку із цим застосування спеціальних знань під час розслідування фальсифікації й обігу фальсифікованих лікарських засобів, а також правильне розуміння слідчим усього комплексу можливостей, які відкриваються в разі застосування різних форм спеціальних знань, виступає підгрунтям ефективного розслідування досліджуваного кримінального правопорушення.

Аналіз останніх досліджень. Значний внесок у розроблення теоретичних основ застосування спеціальних знань у досудовому розслідуванні кримінальних правопорушень зробили відомі вчені-криміналісти: Г.К. Авдєєва, В. П. Бахін, Є.Є. Демидова, В.А. Журавель, В.Г. Гончаренко, Н.І. Клименко, В.В. Коваленко, К.В. Легких, О.В. Одерій, М.В. Салтевський, Е.Б. Сімакова-Сфремян, В.М. Шевчук, В.Ю. Шепітько, М.Г. Щербаковський, В.О. Яремчук та ін.

Однак натепер як у теорії криміналістики, так і на практиці наявні проблеми, пов'язані із застосуванням спеціальних знань під час розслідування окремих видів кримінальних правопорушень, які залишаються дискусійними та потребують вирішення. Крім того, необхідно звернути увагу на те, що в сучасній криміналістичній літературі під час формування методики розслідування фальсифікації та обігу фальсифікованих лікарських засобів розглядаються лише окремі питання означеної проблематики, найчастіше вони присвячені висвітленню деяких питань проведення судової експертизи, залишають поза увагою інші форми застосування 
в розслідуванні розглядуваних нами кримінальних правопорушень. Наведене підтверджує актуальність вказаної теми та необхідність подальших досліджень зазначеної проблематики.

Метою статті є дослідження проблем застосування спеціальних знань під час розслідування окремих видів (груп) кримінальних правопорушень, їх значення в підвищені ефективності досудового розслідування та судового розгляду, аналіз практики застосування основних форм спеціальних знань у розслідуванні фальсифікації й обігу фальсифікованих лікарських засобів, з'ясування їхнього впливу на якість та результативність досудового розслідування цієї категорії кримінальних правопорушень, формування криміналістичних рекомендацій, спрямованих на оптимізацію слідчої, експертної та судової діяльності, а також визначення найбільш перспективних подальших напрямів криміналістичних досліджень розглядуваної проблематики.

Виклад основного матеріалу дослідження. Успіх і ефективність розслідування фальсифікації й обігу фальсифікованих лікарських засобів залежать від знання слідчим специфіки застосування різних форм спеціальних знань, уміле використання яких дає можливість суттєво оптимізувати процес кримінального провадження та зібрати необхідну доказову базу. Тому, на наш погляд, дослідження особливостей застосування спеціальних знань під час розслідування фальсифікації та обігу фальсифікованих лікарських засобів передусім передбачає необхідність з'ясування сутності та можливостей застосування спеціальних знань у розслідуванні кримінальних правопорушень, зокрема і таких досить поширених нині в Україні кримінальних проявів, як фальсифікація й обіг фальсифікованих лікарських засобів.

У спеціальній літературі наявні різні наукові підходи щодо визначення спеціальних знань. Так, В. Г. Гончаренко зазначає, що спеціальними знаннями у кримінальному судочинстві є знання і навички, одержані в результаті фахової освіти та/або практичної діяльності в будь-якій галузі науки, техніки, мистецтва або ремесла, які використовуються визначеними законом учасниками процесу в межах наданих кожному з них повноважень для вирішення за певною процедурою процесуальних завдань [1, с. 24]. М.В. Салтевський під спеціальними знаннями розумів постійно вдосконалювані набуті знання, уміння та навички, які використовуються в будь-якій області людської діяльності, отримані у процесі спеціальної освіти, досвіду і практичної діяльності (за винятком професійних знань осіб, що здійснюють розслідування), необхідні для швидкого і повного розкриття і розслідування злочину, а також розгляду справи в суді [2, с. 184]. На думку В.Ю. Шепітька, спеціальні знання треба розуміти як знання в галузі науки, техніки, мистецтва, ремесла та знання і навички в конкретних видах діяльності, необхідні для їх використання в судочинстві [3, с. 325].

Як зазначає В.Ю. Шепітько, у кримінальній процесуальній діяльності спеціальні знання використовуються у трьох формах: у разі залучення спеціалістів під час окремих слідчих (розшукових) чи судових дій (ч. 8 ст. 228, ч. 3 ст. 237 , ч. 1 ст. 238 , ч. 3 ст. 359 та ін.), у формі консультацій та роз'яснень спеціалістів (ст. ст. 71, 72, 360 Кримінального процесуального кодексу (далі - КПК), у межах 
проведення експертизи (ст. ст. 242, 332 КПК). Під час здійснення правосуддя велику допомогу слідству та суду надає судова експертиза [4, с. 422]. Як свідчать результати узагальнення матеріалів слідчо-судової практики, серед основних форм використання спеціальних знань під час розслідування фальсифікації й обігу фальсифікованих лікарських засобів найбільш поширені такі: проведення судової експертизи; залучення спеціалістів під час проведення окремих слідчих (розшукових), судових дій чи забезпечувальних заходів; отримання консультацій та роз'яснень спеціалістів.

Водночас результати анкетування співробітників Національної поліції України та Служби безпеки України показали, що під час розслідування фальсифікації та обігу фальсифікованих лікарських засобів нерідко практичні працівники ставляться до застосування спеціальних знань формально, ігнорують можливості їх використання, що, звичайно, негативно впливає на ефективність та результативність виявлення, розслідування та профілактики таких кримінальних правопорушень. Так, іноді спеціалісти не залучалися взагалі, судові експертизи проводилися більше двох місяців або взагалі не проводилися, оскільки використовувався висновок спеціаліста. Наведене свідчить про необхідність активізації пошуку прихованих резервів та можливостей застосування спеціальних знань, спрямованих на підвищення ефективності досудового розслідування досліджуваної категорії кримінальних правопорушень.

Отже, найбільш поширеною формою застосування спеціальних знань під час розслідування вказаної категорії злочинів є судова експертиза. Результати узагальнення матеріалів слідчо-судової практики показали, що для розслідування цієї категорії кримінальних правопорушень найчастіше призначають такі види судових експертиз, як: судово-фармацевтична (судово-хімічна), судово-фармакологічна, судово-медична, судово-товарознавча, технічна експертиза документів, судово-почеркознавча, експертиза звукозапису, комп'ютерно-технічна, економічна, судово-психіатрична, судово-психологічна тощо.

Найбільш характерне під час розслідування цієї категорії кримінальних правопорушень призначення судово-фармацевтичної експертизи, яка посідає особливе місце серед судових експертиз. Судово-фармацевтична експертиза являє собою новий вид судово-експертних досліджень і дозволяє отримати важливі дані, які можуть бути використані для проведення всебічного й об'єктивного розслідування розглядуваних кримінальних правопорушень.

Як показує вивчення матеріалів кримінальних проваджень, слідчі в разі призначення судових експертиз із метою дослідження фальсифікованих лікарських засобів нерідко плутають «судову-хімічну», «судову-токсикологічну», «біологічну», «фармацевтичну» та «фармакологічну» експертизи. Пояснюється це передусім складністю об’єктів дослідження, ігноруванням такої форми застосування спеціальних знань, як отримання консультацій та роз'яснень спеціалістів. Крім цього, лікарські засоби, представлені на дослідження, можуть бути об'єктом вивчення всіх вищезгаданих судових експертиз, оскільки мають різноманітну природу, можуть бути як неорганічними, так і органічними (починаючи з найпростіших аліфатичних речовин до найскладніших макромолекулярних структур), 
синтетичного та природного походження, а також можуть являти собою індивідуальні речовини або багатокомпонентні суміші. Різноманітний також діапазон концентрацій лікарських речовин як об'єкт судово-експертного дослідження.

Судово-фармацевтична експертиза покликана вирішити комплекс завдань, пов'язаних із визначенням відповідності складу, якості й інших органолептичних властивостей фармацевтичних препаратів встановленим вимогам. Об'єктами та сферою вивчення фармацевтичної хімії є хімічні процеси під час створення, подальшої трансформації та зберігання лікарських засобів, виявлення діючої речовини і домішок, визначення їхньої справжності. Проведення судово-фармацевтичної експертизи базується на методах аналітичної (фармацевтична) хімії. 3 огляду на викладене, судово-фармацевтичну експертизу в матеріалах кримінальних проваджень іноді позначають як судово-хімічну тощо. Тому судово-фармацевтичну експертизу необхідно відмежовувати від інших видів судових експертиз.

Крім цього, не можна погодитися з позицією окремих науковців (О.Г. Гук, Н.Ф. Файзрахманов), які до об'єктів судово-фармацевтичної або судово-хімічної експертизи відносять упаковки лікарських засобів. Так, на думку Н.Ф. Файзрахманова [5], яку підтримує і О.Г. Гук [6], для вирішення криміналістичного дослідження упаковок лікарських засобів в рамках цієї експертизи можуть бути поставлені як діагностичні питання: 1) яким способом виконано зображення на упаковці; 2) яке обладнання було використано для виконання зображення; 3) яким чином виготовлені друковані форми, застосовані для нанесення зображення; так і ідентифікаційні: 1) з використанням тієї самої або різних друкарських форм (комплекти друкованих форм) виконані зображення на представлених упаковках; 2) чи не виконано зображення на представленій упаковці з використанням даної друкованої форми; 3) якого роду (виду) матеріали (папір, фарбувальні речовини, клей, поверхневе покриття) застосовувалися для виготовлення представленої упаковки? На наш погляд, проведення дослідження упаковок лікарських засобів не може бути предметом судово-фармацевтичної експертизи, а має проводитись виключно в рамках технічної експертизи документів.

Серед типових питань, що ставляться перед експертом у разі призначення судово-фармацевтичної експертизи, можна виокремити такі:

1. Чи є представлена на дослідження речовина лікарським засобом, якщо так, то яким саме?

2. Яка природа наданої для дослідження речовини, ії компонентний склад, кількісні та вагові показники, фізико-хімічні властивості?

3. Чи відповідають хімічний склад, дозування та технологія виготовлення речовини, наданої для дослідження, встановленим стандартам; відомостям, зазначеним на упаковці і в інструкції з їі застосування?

4. Яка фармацевтична активна речовина (речовини) входить (входять) до складу наданої для дослідження речовини, чи належать вони до категорії наркотичних засобів, психотропних речовин або їх прекурсорів, сильнодіючих або отруйних речовин?

5. Чи є у представленій для дослідження речовині сторонні домішки, якщо є, то які саме? Яка кількість цих домішок, чи не є вони отруйними? 
6. Чи належать представлені на дослідження лікарські засоби до однієї партії?

Варто зауважити, що зазначений перелік питань, що ставляться експерту в разі призначення цієї судової експертизи, є досить умовним, у конкретній слідчій ситуації він може бути розширений із включенням тих питань, що мають значення для досудового розслідування та судового провадження.

Велике значення для ефективного процесу збору доказової інформації під час розслідування фальсифікації й обігу фальсифікованих лікарських засобів має дослідження можливостей судово-фармакологічної та судово-медичної експертиз. Очевидно, що судово-фармакологічна експертиза оперує знаннями у сфері фармакології, тобто науки, що займається вивченням впливу лікарських засобів на життя і здоров'я людей та інших біологічних об'єктів (впливу фізіологічно активних речовин на біологічні системи). За результатами експертного дослідження вона виявляє місцеву і загальну дію на організм певних речовин, з'ясовує отруйність лікарських засобів у кількісному і ситуаційному аспектах, вивчає залежність їхнього впливу на організм людини від різноманітних чинників об'єктивного і суб'єктивного характеру, умови кумуляції, протипоказання тощо [7, с. 199]. Отже, судово-фармакологічна експертиза здатна вирішувати питання ситуаційного характеру, зокрема щодо реакції організму на вживання тих чи інших лікарських засобів у певній кількості, залежно від конкретних об'єктивних і суб'єктивних чинників, наявності протипоказань тощо.

Необхідність призначення судово-медичної експертизи виникає зазвичай тоді, коли фактичне вживання фальсифікованих лікарських засобів спричинило в пацієнта погіршення перебігу хвороби, ускладнення, інші тяжкі наслідки аж до летального. Така судово-медична експертиза розглядає специфічне коло питань, основні з яких, на нашу думку, такі:

1. Чи потребувала особа кваліфікованої медичної допомоги відповідно до встановленого медичного діагнозу? Чи своєчасно їй було надано медичну допомогу?

2. Чи правильно було призначене лікування з погляду вибору лікарських засобів, чи враховані були протипоказання, індивідуальна непереносимість препаратів?

3. Чи були які-небудь недоліки лікування, пов'язані із вживанням хворим лікарських засобів, чи перебувають вони у причинно-наслідковому зв'язку з погіршенням стану здоров'я й іншими тяжкими наслідками?

4. Які саме тяжкі наслідки для хворого спричинені прийняттям лікарських засобів?

Означений перелік питань має загальний характер та може доповнюватися і змінюватися залежно від обставин, що підлягають з'ясуванню, та ситуацій розслідування, що потребують застосування відповідних спеціальних знань під час розслідування досліджуваних кримінальних правопорушень.

Суттєве значення для кваліфікації діяння й оцінки завданої правопорушенням шкоди під час розслідування таких кримінальних правопорушень має судово-товарознавча експертиза фальсифікованих лікарських засобів. Так, відповідно до ч. ч. 2 та 3 ст. $321^{1}$ Кримінального кодексу України, кваліфікованим складом злочину є виготовлення, придбання, перевезення, пересилання, зберігання з метою збуту або збут завідомо фальсифікованих лікарських засобів, зокрема у великих 
або особливо великих розмірах, а також виробництво фальсифікованих лікарських засобів. Нині розмір фальсифікованих лікарських засобів під час визначення кваліфікуючої чи особливо кваліфікуючої ознаки кримінального правопорушення у вигляді фальсифікації лікарських засобів або обігу фальсифікованих лікарських засобів визначається із застосуванням положень наказу Міністерства охорони здоров’ я України від 22 квітня 2013 р. № 321 «Про визначення понять «великі» та «особливо великі» розміри фальсифікованих лікарських засобів», відповідно до норм якого під великим розміром фальсифікованих лікарських засобів варто розуміти лікарські засоби, вартість яких становить від п'ятдесяти до п'ятисот неоподатковуваних мінімумів доходів громадян, а під особливо великим розміром фальсифікованих лікарських засобів варто розуміти лікарські засоби, вартість яких становить п’ятсот і більше неоподатковуваних мінімумів доходів громадян [8].

Отже, важливими обставинами, які підлягають з'ясуванню під час розслідування цієї категорії кримінальних правопорушень, є роздрібна вартість виявлених фальсифікованих лікарських засобів, а також спосіб їх виготовлення: промисловий, тобто певними серіями, за певним стандартом (норма, зразок, мірило), що має задовольняти певним вимогам щодо якості, хімічного складу, фізичних властивостей, ваги, форм і розмірів, або саморобний. Так, наприклад, згідно з висновком судово-товарознавчої експертизи, проведеної Харківським науково-дослідним інститутом судових експертиз ім. засл. проф. М.С. Бокаріуса в рамках кримінального провадження щодо виготовлення та збуту фальсифікованих лікарських засобів на території міста Харкова [9], загальна ринкова вартість фальсифікованих лікарських засобів становила майже 267 198,12 грн. Саме проведення судово-товарознавчої експертизи, за результатами якої було встановлено перевищення роздрібної вартості фальсифікованих лікарських засобів великого розміру, встановленої наказом Міністерства охорони здоров’я України від 22 квітня 2013 р. № 321, дозволило кваліфікувати вказане діяння за ч. 2 ст. $321^{1}$ Кримінального кодексу України.

Серед питань, що ставляться перед експертом у разі призначення судово-товарознавчої експертизи, особливого значення набувають такі:

1. Яка роздрібна вартість кожного окремо та загальна вартість усіх вилучених фальсифікованих лікарських засобів станом на певний момент часу за умови їхньої придатності до реалізації?

2. Яким способом виготовлено фальсифіковані лікарські засоби, промисловим або саморобним?

3. Чи є ознаки серійного виготовлення фальсифікованих лікарських засобів?

Очевидно, що зазначений перелік питань, що ставляться експерту в разі призначення цієї судової експертизи, є типовим і умовним, тому з урахуванням певних слідчих ситуацій може бути доповнений, розширений, виходячи з конкретних обставин кримінального провадження.

Аналіз матеріалів слідчо-судової практики дозволяє констатувати, що техніко-криміналістичні експертизи документів не завжди призначаються в ситуаціях, коли звернення до цієї форми спеціальних знань необхідне. Справді, сучасний рівень розвитку засобів поліграфічної техніки зумовлює широке застосування 
злочинцями окремих документів, що мають ознаки інтелектуальної підробки, тобто документів, які мають усі реквізити, оформлені формально правильно, але не відповідають дійсності. Так, наприклад, розпорядженням Держлікслужби від 15 квітня 2019 р. № 3087-001.1/002.0/17-19 заборонено реалізацію, зберігання та застосування лікарського засобу ЕТАНОЛ 96, розчину для зовнішнього застосування 96\% по 100 мл у флаконах, серії 051016, з маркуванням виробника ПП «Кілафф» (Україна), що реалізується із сертифікатом якості, що має ознаку фальсифікації, а саме у фальсифікованому сертифікаті якості виробника зазначено розмір серії - 115015 флаконів (в оригінальному сертифікаті якості виробника зазначено розмір серії - 5015 флаконів). Наведені обставини з'ясовуються досудовим розслідуванням у кримінальному провадженні № 12018150040001992 від 17 травня 2018 р. за ознаками вчинення кримінального правопорушення, передбаченого ч. 2 ст. $321^{1}$ Кримінального кодексу України [10].

Вбачається, що ситуації призначення техніко-криміналістичних експертиз під час розслідування вказаної категорії злочинів переважно пов'язані із встановленням способу виготовлення або підробки документів, зокрема: 1) правовстановлюючих та дозвільних документів установ, підприємств, організацій, які займаються оптовою та роздрібної торгівлею лікарськими засобами: ліцензій, сертифікатів якості виробника, наказів з особового складу, іншої дозвільної документації; 2) господарської документації на лікарські засоби: товарних накладних, рахунків, актів прийому-передачі, списання товарів, договорів поставок тощо; 3) етикеток, упаковок, інструкцій лікарських засобів.

Як показує практика, техніко-криміналістична експертиза упаковки лікарського засобу може призначатися для вирішення таких типових питань:

1. Яким способом виконано зображення на упаковці?

2. Яке обладнання було використано для нанесення зображення?

3. Чи виконані зображення на упаковках за технологією, яка використовується на підприємстві-виробнику оригінальної продукції?

4. З використанням тієї самої або різних друкарських форм (комплектів друкованих форм) виконані зображення на представлених упаковках?

5. Якого роду (виду) матеріали (папір, фарбувальні речовини, клей, поверхневе покриття) застосовувалися для виготовлення представленої упаковки?

6. Чи виготовлені упаковки за допомогою матеріалів, зразки яких представлені на дослідження?

Проведення судово-почеркознавчої експертизи рукописних текстів під час розслідування фальсифікації та обігу фальсифікованих лікарських засобів є доцільним за наявності слідчої ситуації, пов’язаної з необхідністю визначення виконавця письмових записів і підпису на документах легальних фармацевтичних підприємств, зокрема на договорах, видаткових накладних, наказах, розпорядженнях тощо. Така необхідність зазвичай зумовлена ситуацією, коли посадова особа фармацевтичного підприємства заперечує свою участь у порушенні встановлених правил обігу лікарських засобів.

Так, зокрема, допитана в судовому засіданні [11] завідувач аптеки № 1 ГТОВ «Л-Фарма» в м. Лубни вказала, що походження предметів, які в обвинувальному 
акті зазначені як фальсифіковані лікарські засоби, їй невідоме, фальсифікованих лікарських засобів не виготовляла і не зберігала, документів не підписувала. Водночас висновками почеркознавчих експертиз, проведених у вказаному кримінальному провадженні, було встановлено належність підпису на документах (журнали лабораторно-фасувальних робіт, акти списання, прибуткові накладні), необхідних для надання вигляду законності виготовленню завідомо фальсифікованих лікарських засобів, саме цій особі.

Аналіз слідчо-судової практики показує, що під час розслідування кримінальних правопорушень досліджуваної категорії досить часто проводяться негласні слідчі (розшукові) дії й оперативно-розшукові заходи, пов'язані зі зняттям інформації із транспортних телекомунікаційних мереж. Це цілком відображає специфіку виявлення організованого характеру таких кримінальних правопорушень, оскільки здебільшого співучасники, зокрема й керівники, спілкувалися один з одним за допомогою засобів зв'язку [12].

Однак проведення негласної слідчої (розшукової) дії зняття інформації із транспортних телекомунікаційних мереж саме по собою, якщо воно не підкріплюється результатами судової експертизи звукозапису, стає недостатнім для встановлення досліджуваних фактів. У зв'язку із цим, щоб уникнути прогалин в доказовій базі, а також клопотань про визнання недопустимими результатів проведення негласної слідчої (розшукової) дії зняття інформації із транспортних телекомунікаційних мереж, доцільно призначати і проводити судову експертизу звукозапису, на вирішення якої доцільно ставити питання: 1) ідентифікації людини за голосом і мовою; 2) визначення кількості осіб, які брали участь у розмові, зафіксованій на фонограмі; 3) визначення дослівного змісту розмови; 4) визначення наявності у фонограми ознак монтажу, змін, внесених після запису; 5) визначення факту застосування технічних засобів для зміни голосу особи.

Характерним явищем для сучасних умов ведення господарської діяльності є наявність значної кількості електронних документів, що використовуються фармацевтичними підприємствами в діловому листуванні, що зумовлено прийнятою практикою документообігу з використанням сканованих копій різних документів. 3 метою встановлення робочого стану комп'ютерно-технічних засобів, установлення обставин, пов'язаних із використанням комп'ютерно-технічних засобів, інформації та програмного забезпечення, виявлення інформації та програмного забезпечення, що містяться на комп'ютерних носіях, треба призначати комп'ютерно-технічну експертизу.

Важливим аспектом господарської діяльності сучасних фармацевтичних підприємств також є необхідність ведення бухгалтерського обліку та формування первинних господарських документів. У зв'язку із цим для визначення документальної обгрунтованості розміру нестачі або надлишків товарно-матеріальних цінностей (зокрема, лікарських засобів, сировини, пакувальних матеріалів) і грошових коштів, періоду і місця їх утворення в господарській діяльності підприємства варто призначати економічну експертизу.

У деяких випадках під час розслідування фальсифікації й обігу фальсифікованих лікарських засобів також необхідне призначення судово-психіатричної 
експертизи з метою визначення психічного стану осіб, у конкретні проміжки часу і щодо певних обставин, що становлять інтерес для органів слідства або суду. Крім того, для встановлення особливостей психічної діяльності та проявів у поведінці особи, які мають юридичне значення та викликають певні правові наслідки, доцільним є проведення судово-психологічної експертизи.

Водночас варто вказати на наявність у слідчо-судовій практиці суттєвих недоліків, пов'язаних із нехтуванням застосуванням спеціальних знань, яке зумовило визнання недійсними значної кількості доказового матеріалу та, зрештою, спричинило винесення виправдувального вироку. Зокрема, як було зазначено судом у справі щодо обвинувачення групи осіб у вчиненні фальсифікації й обігу фальсифікованих лікарських засобів на території Полтавської області [11], серед матеріалів кримінального провадження немає документів про призначення стороною обвинувачення експертиз або дослідження спеціалістами, серед іншого, речових доказів із питань: 1) відповідності чи невідповідності речовини лікарського засобу встановленим вимогам; 2) руху лікарських засобів, пакувальних матеріалів, сировини за первинними бухгалтерськими документами, зокрема, які саме флакони, контейнери тощо використовувались для упаковки яких саме предметів, що в обвинувальному акті зазначені як фальсифіковані лікарські засоби; 3) визначення способу виготовлення фальсифікованих лікарських засобів як «виготовлення шляхом зміни зареєстрованих форм випуску (розфасовки в неналежному порядку у флакони з меншим вмістом і концентрацією)»; 4) визначення вартості тих предметів, що в обвинувальному акті зазначені як фальсифіковані лікарські засоби. Усі інші документи та речові докази, зібрані під час досудового розслідування, на думку суду, могли бути використані як підстава для призначення судових експертиз у кримінальному провадженні, але не можуть підміняти висновки експертів у кримінальному провадженні.

Важливою формою застосування спеціальних знань у розслідуванні фальсифікації й обігу фальсифікованих лікарських засобів є залучення спеціалістів під час проведення слідчих (розшукових), судових дій чи забезпечувальних заходів. Суттєве значення застосування цієї форми спеціальних знань зумовлене можливістю спеціаліста істотно доповнити уявлення слідчого, прокурора про подію злочину, професійно здійснювати пошук, вилучення й упакування слідів, речових доказів, а в деяких випадках і запобігти помилковим висновкам та висуненню неправильних версій. У зв'язку із цим слушною є думка про те, що спеціаліст - це особа, яка не підміняє слідчого, це обізнана в певній галузі особа, покликана своїми спеціальними знаннями допомогти слідчому тоді, коли з питань, що мають значення для справи, потрібна фахова допомога [13, с. 31-32].

Особливо важливим залучення спеціаліста до проведення слідчих (розшукових), судових дій, а також забезпечувальних заходів $є$ через низький рівень технічного оснащення органів досудового розслідування, у зв'язку із чим великого значення для успішного розслідування досліджуваної категорії кримінальних проваджень набуває надання спеціалістами допомоги в застосуванні можливостей різних технічних засобів. Здебільшого ознаки фальсифікованих лікарських засобів виявлено саме за допомогою спеціальних технічних засобів, як-от верифікатори, спеціальні 
мікроскопи, люмінесцентний опромінювач, дифракційні плівки тощо. Виявлення фальсифікації лікарських засобів за допомогою інфрачервоних і ультрафіолетових опромінювачів засноване на флюоресціюючому сяйві пакувальних матеріалів: етикеток, плівки, блістерів, контейнерів, паперу інструкцій тощо. Виявлення прихованих захисних знаків на упаковці здійснюється за допомогою опромінювачів і накладення спеціальних дифракційних плівок. Ідентифікація захисних наклейок і голограм проводиться із застосуванням версифікаторів [5, с. 21]. У значній кількості кримінальних проваджень технічні засоби взагалі не застосовувалися, що потребує з'ясування причин та пошуку можливостей їх усунення.

Відповідно до даних узагальнення матеріалів слідчої та судової практики під час розслідування фальсифікації й обігу фальсифікованих лікарських засобів, найчастіше спеціаліст, відповідно до його обов'язків, передбачених у ст. 71 КПК, реалізовує свої спеціальні знання, навички та досвід шляхом надання слідчому допомоги в таких формах, як [14, с. 129]: 1) технічна - полягає в допомозі у виявленні, вилученні та фіксації доказів; 2) консультаційна - полягає, наприклад, у роз'ясненні особливостей встановлення контакту під час допиту неповнолітнього, створення обстановки проведення слідчого експерименту; 3) довідкова - роз'яснення спеціальних термінів, необхідних реквізитів певних документів; 4) інформаційна - як ставити запитання учасникам вербальних слідчих дій; 5) організаційно-технічна полягає в допомозі викреслювати схеми, плани, складати протокол слідчої дії.

За результатами узагальнення матеріалів кримінальних проваджень розглядуваної категорії кримінальних правопорушень найчастіше залучення спеціалістів мало місце під час проведення огляду місця події, огляду фальсифікованих лікарських засобів, обшуку, що суттєво впливає на підвищення ефективності та якості досудового розслідування таких кримінальних проявів. Водночас такі дані потребують додаткового вивчення з метою активізації та розширення можливостей застосування спеціальних знань під час проведення інших слідчих (розшукових), судових дій та забезпечувальних заходів. Наведене може забезпечити пошук прихованих резервів оптимізації та підвищення результативності слідчої, експертної та судової діяльності.

У зв'язку із цим необхідно звернути увагу на деякі недоліки, що пов'язані з нехтуванням спеціальними знаннями під час проведення окремих слідчих (розшукових) дій. Так, насамперед варто звернути увагу на досить низький рівень залучення спеціалістів під час огляду та вилучення фальсифікованих лікарських засобів. Відсутність використання спеціальних знань у цьому разі суттєво впливає на результат, оскільки неповне або неправильне їх вилучення може призвести до втрати важливої доказової інформації та завдати шкоди досудовому розслідуванню. Актуальним під час розслідування цієї категорії кримінальних правопорушень є залучення спеціалістів у разі необхідності відібрання зразків. Слушним є зауваження В.Ю. Шепітько, що відібрані зразки повинні мати репрезентативність (достатню кількість та якість) і порівняльність (можливість порівняння), але слідчий не завжди дотримується цих вимог під час відбору та дослідження зразків для судової експертизи [15, с. 18-19]. Крім цього, самостійне (без допомоги спеціаліста) вилучення слідчим, прокурором речових доказів часто провадиться 
з порушенням встановлених вимог, що призводить до неможливості вирішення експертних завдань [16, с. 135].

У практиці розслідування досліджуваних різновидів кримінальних правопорушень нерідко спостерігається ще один недолік, який безпосередньо пов'язаний із вищеозначеними, зокрема, у протоколах огляду й обшуку наявні окремі прогалини, які вказують на відсутність не лише відомостей про ознаки фальсифікації на вилучених під час обшуку лікарських засобах, які можуть бути виявлені із застосування спеціальних знань, як-от відсутність мікротексту, шрифту Брайля, прихованих зображень або спеціальних дефектів; відсутність захисних волокон та смужок, мікрочастинок, хімічних міток, відмінності у фармакоді, а й ознак, які можуть бути виявлені неозброєним оком, як-от відмінність вилучених засобів одного найменування за висотою і діаметром флаконів, відмінності в чіткості відтиску, розмиття барвника, відмінності шрифту, низька якість прикріплення етикетки до флакона, низька міцність і цілісність окремих елементів лікарського засобу, відсутність інструкції в деяких упаковках лікарського засобу.

Досить поширеною формою застосування спеціальних знань під час розслідування фальсифікації й обігу фальсифікованих лікарських засобів є отрилання консультацій та роз'яснень спеціалістів. Однак у криміналістичній літературі існують різні підходи щодо доказового значення таких роз'яснень, а також доцільності їх застосування поряд із висновком експерта. Варто зазначити, що процесуальні становища експерта та спеціаліста суттєво різняться. Розбіжність полягає в тому, що спеціаліст надає слідчому лише науково-технічну допомогу під час проведення слідчої (розшукової) дії. Спеціаліст, завдяки обізнаності в окремій галузі, бере участь у виявленні, фіксації, вилученні слідів речових доказів, надає консультативну допомогу під час проведення слідчих (розшукових) дій. Пояснення спеціаліста і висновки, наявні в них, не є доказами. Водночас експерт у результаті дослідження об'єктів експертизи надає висновок, що є самостійним джерелом доказів [17, с. 75].

Узагальнення матеріалів слідчої та судової практики розслідування досліджуваної категорії кримінальних правопорушень дозволяє дійти висновку про широке застосування судами висновку щодо якості лікарських засобів, наданого підрозділами Державної служби з лікарських засобів та контролю за наркотиками, як окремого письмового доказу в разі відсутності проведення експертного дослідження. Так, зокрема, одним з основних доказів винуватості злочинців у судовому розгляді судової справи Жовтневим районним судом міста Запоріжжя [18] став висновок щодо якості № 0037 від 29 травня 2017 р. Лабораторії з контролю якості лікарських засобів та медичної продукції Державної служби з лікарських засобів та контролю за наркотиками в Київській області, відповідно до якого перевірений зразок «ЕТАНОЛ 96\% », розчин по 100 мл у флаконах серії № 010116 виробництва ТОВ «Фарма Черкас» (Україна) не відповідає вимогам МКЯ ЛЗ до РП № UA/14597/01/02 від 3 вересня 2015 р. за такими показниками, як: ідентифікація (завищений); відносна густина (завищений); об’єм вмісту упаковки (занижений); упаковка (на одному із 78 перевірених флаконів наявне протікання лікарського засобу з-під кришки флакона. Етикетки проклеєні не по всій площі, наявні пухирці на поверхні етикетки). 
У контексті цього дискусійною є позиція О.В. Одерія, відповідно до якої нині можливо призначати судову експертизу одразу після внесення відомостей до Єдиного реєстру досудових розслідувань, а отже, немає потреби у «висновках», «довідках" спеціаліста [19, с. 231]. Варто погодитись із твердженням В.О. Яремчук про те, що отримання висновку спеціаліста - менш тривала за часом процедура порівняно з експертним дослідженням, тому не варто відмовлятися від його використання [20, с. 114]. Справді, як убачається з результатів узагальнення матеріалів слідчо-судової практики розслідування фальсифікації й обігу фальсифікованих лікарських засобів, велика кількість судових експертиз у досліджуваній категорії кримінальних правопорушень проводиться в термін більше місяця, у зв'язку із чим на початку розслідування існує нагальна потреба в отриманні консультацій та роз'яснень спеціалістів, які б дозволили, з одного боку, скласти кваліфіковане уявлення про механізму вчинення злочину, висунути слідчі версії та правильно визначити напрями розслідування, з іншого - обгрунтувати необхідність слідчих (розшукових) дій, які проводяться на підставі ухвали слідчого судді або за рішенням прокурора.

Варто наголосити, що консультації та роз'яснення спеціалістів не можуть замінити проведення відповідних експертиз, оскільки, з одного боку, не дозволяють розв'язати всі питання, доступні в рамках експертного дослідження, а з іншого не мають відповідного процесуального статусу та доказового значення.

Отримання консультацій та роз'яснень спеціалістів під час розслідування фальсифікації та обігу фальсифікованих лікарських засобів зазвичай здійснюється за взаємодії із співробітниками Державної служби України з лікарських засобів та контролю за наркотиками, насамперед виявляється в: 1) оцінці конкретного зразка лікарського засобу на предмет відповідності чинним вимогам Методів контролю якості до реєстраційного посвідчення лікарського засобу; 2) наданні консультацій щодо нормативної документації, яка регламентує порядок виробництва та збуту лікарських засобів; 3) з'ясуванні особливостей технології виробництва, в організації контролю на підприємстві, де виробляють або реалізують лікарські засоби; 4) визначенні переліку документів, необхідних під час фармацевтичної діяльності підприємства, установи чи організації, порядку й особливостей документообігу; 5) рекомендаціях щодо спеціальної технічної, наукової та методичної літератури; 6) наданні роз'яснень щодо необхідності проведення експертиз та змісту питань, які потрібно поставити експерту.

Отже, підсумовуючи наведене, варто зазначити, що ефективне проведення розслідування фальсифікації та обігу фальсифікованих лікарських засобів передбачає знання слідчим усього комплексу можливостей, які відкриваються в разі застосування різних форм спеціальних знань, зокрема: залучення спеціалістів під час проведення окремих слідчих (розшукових), судових дій чи забезпечувальних заходів, отримання консультацій та роз'яснень спеціалістів, проведення судової експертизи. Кожна з наведених форм застосування спеціальних знань має свою специфіку. Так, за допомогою спеціаліста можна звернути увагу слідчого на деякі криміналістично значущі ознаки фальсифікації та обігу фальсифікованих лікарських засобів, як-от можливі сліди дії механізмів, верстатів, сприяти з'ясуванню 
способу фальсифікації, особливостей технологічного процесу, сутності порушень правил та норм ліцензійних умов із виробництва лікарських засобів, а також консультації щодо термінологічно правильного опису обставин події у процесуальних документах, тоді як висновки експертів мають істотне доказове значення, тому не можуть бути замінені іншими доказами, що підтверджується матеріалами слідчо-судової практики.

Характерною для аналізованої категорії злочинів є потреба у призначенні судово-фармацевтичної, фармакологічної, судово-медичної, судово-товарознавчої та технічної експертиз документів. Варто зазначити, що слідчі нерідко зазнають труднощів із вибором вищевказаних і суміжних видів судових експертиз, що зумовлює необхідність уточнення сфери досліджень, можливостей цих експертиз, типових питань, які вирішуються експертами, а також інших особливостей проведення вказаних експертних досліджень. Важливим також є питання вибору форми застосування спеціальних знань, оскільки слідчі не завжди вважають за потрібне призначати судово-фармацевтичні експертизи, обмежуються долученням до матеріалів кримінального провадження протоколів випробувань або оцінки якості лікарських засобів, що проводяться в рамках відомчої діяльності Державної служби з лікарських засобів та контролю за наркотиками. У зв'язку із чим варто наголосити, що такі документи, у результаті яких лікарські засоби визнаються фальсифікованими та вилучаються з легального обігу, не можуть замінити проведення фармацевтичної експертизи, оскільки можливості таких випробувань, проведених поза кримінальним процесуальним законом, з одного боку, не дозволяють розв’язати всі питання, доступні в рамках експертного дослідження, а з іншого не мають необхідної доказової сили.

\section{Jimepamypa}

1. Гончаренко В.Г., Курдюков В.В., Легких К.В. Спеціальні знання: генезис, предмет, рівні, форми використання в доказуванні. Вісник Акаделї̈ адвокатури України. 2007. Вип. 2. С. 22-34.

2. Салтевський М.В. Криміналістика (у сучасному викладі). Київ : Кондор, 2005. 586 с.

3. Шепітько В.Ю. Велика юридична енциклопедія : у 20-ти т. Нац. акад. прав. наук України ; Нац. юрид. ун-т ім. Ярослава Мудрого. 2018. Т. 20 : Криміналістика, судова експертиза, юридична психологія. $952 \mathrm{c.}$

4. Шепітько В.Ю. Залучення експерта і спеціаліста та проведення судових експертиз. Криміналістика : підручник : у 2-х т. / В.Ю. Шепітько та ін. ; за ред. В.Ю. Шепітька. Харків : Право, 2019. T. 1. С. $422-445$.

5. Файзрахманов Н.Ф. Расследование оборота фальсифицированных и недоброкачественных лекарственных средств, биологически активных добавок : автореф. дис. ... канд. юрид. наук. Москва, 2013. 30 c.

6. Гук О.Г. Розслідування фальсифікації лікарських засобів та обігу фальсифікованих лікарських засобів : автореф. дис. ... канд. юрид. наук: 12.00.09. Київ, 2016. 20 с.

7. Експертизи у судочинстві України : науково-практичний посібник за заг. ред. В.Г. Гончаренко, І.В. Гори. Київ : Юрінком-Інтер, 2015. 504 с.

8. Про визначення понять «великі» та «особливо великі» розміри фальсифікованих лікарських засобів : наказ Міністерства охорони здоров’я України від 22 квітня 2013 р. № 321.

9. Вирок Московського районного суду м. Харкова від 16 вересня 2015 р. у справі № 643/15936/15-к.

10. Ухвала Ленінського районного суду міста Миколаєва від 31 січня 2020 р. у справі № 489/6044/19.

11. Вирок Лубенського міськрайонного суду Полтавської області від 21 лютого 2018 р. у справі 539/1590/15-к. 
12. Вирок Баглійського районного суду м. Дніпродзержинська Дніпропетровської області від 23 листопада 2016 р. № 207/1527/16-к.

13. Винберг А.И. Специалист в процессе предварительного расследования. Социалистическая законность. 1961. № 9. С. 31-32.

14. Яремчук В.О. Функції та форми участі спеціаліста під час проведення слідчих дій. Теорія та практика судової експертизи і криміналістики. 2010. Вип. 10. С. 123-130.

15. Шепитько В.Ю. Развитие судебно-экспертной деятельности в Украине: проблемы и перспективы. Теорія та практика судової експертизи і криміналістики. 2002. Вип. 2. С. 18-19.

16. Алексейчук В.І. Огляд місця події: тактика і психологія : монографія / за ред. В.О. Коновалової. Харків : Апостиль, 2011. 176 с.

17. Рівчаченко О.А. Використання спеціальних знань під час розслідування злочинів, пов'язаних із незаконним використанням обладнання, призначеного для виготовлення наркотичних засобів. Науковий вісник національної академії внутрішніх справ. 2015. № 4 (97). С. 74-84.

18. Вирок Жовтневого районного суду міста Запоріжжя від 7 серпня 2017 р. у справі № $331 / 4717 / 17$.

19. Одерій О.В. Спеціальні знання у досудовому розслідуванні злочинів. Сучасні проблеми криміналістики : матеріали Міжнародної науково-практичної конференції, Одеса, 27-28 вересня 2013 р. Одеса : Юрид. літ., 2013. С. 229-231.

20. Яремчук В.О. Функції та форми участі спеціаліста під час проведення слідчих дій. Теорія та практика судової експертизи і криміналістики. 2010. Вип. 10. С. 123-130.

\section{Анотація}

Парфило І. В. Проблеми застосування спеціальних знань при розслідуванні фальсифікації та обігу фальсифікованих лікарських засобів. - Стаття.

Стаття присвячена дослідженню актуальних проблемам застосування спеціальних знань під час розслідування фальсифікації та обігу фальсифікованих лікарських засобів. Обгрунтовано, що найбільш поширеними формами застосування спеціальних знань у розслідуванні вказаної категорії кримінальних правопорушень є проведення судової експертизи, залучення спеціалістів під час проведення окремих слідчих (розшукових), судових дій чи забезпечувальних заходів, а також отримання консультацій та роз'яснень спеціалістів. Особливу увагу приділено дослідженню чинників, які обумовлюють вибір певної форми застосування спеціальних знань на досудовому розслідуванні кримінальних правопорушень. Проведено критичний аналіз поглядів учених щодо визначення спеціальних знань у кримінальному проваджені, їхньої специфіки застосування в досудовому розслідувані, інших проблем, які є дискусійними у криміналістиці.

Зазначається, що найбільш характерна для таких кримінальних правопорушень необхідність у призначенні судово-фармацевтичної, фармакологічної, судово-медичної, судово-товарознавчої та технічної експертиз документів. 3 огляду на наявність на практиці значних труднощів із вибором вищевказаних і суміжних видів судових експертиз, здійснено аналіз, уточнено предмет і об'єкт досліджень цих експертиз, запропоновано перелік типових питань, які вирішуються експертами у процесі ïx проведення. Обгрунтовується важливість правильного вибору тієї чи іншої форми застосування спеціальних знань під час розслідування досліджуваних кримінальних правопорушень, оскільки на практиці судові експертизи нерідко призначаються через декілька місяців проведення слідства, а нерідко органи досудового розслідування обмежуються лише ознайомленням із відомчою документації Державної служби з лікарських засобів та контролю за наркотиками. Зазначається, що висновки спеціаліста та залучення до матеріалів кримінального провадження відомчої документації, на підставі яких лікарські засоби визнаються фальсифікованими та вилучаються з легального обігу, не можуть замінити проведення судово-фармацевтичної експертизи. Ураховуючи специфіку зазначеної категорії кримінальних правопорушень, важливою та значущою постає потреба в подальших наукових розробках означеної проблематики, у додатковому вивченні проблемних питань застосування спеціальних знань, з метою активізації та розширення їхніх можливостей, що може стати важливим кроком в удосконалені формування та реалізації криміналістичної методики розслідування фальсифікації та обігу фальсифікованих лікарських засобів.

Ключові слова: спеціальні знання, форми застосування спеціальних знань, судова експертиза, залучення спеціалістів, отримання консультацій та роз'яснень спеціалістів, судово-фармацевтична експертиза, розслідування фальсифікації та обігу фальсифікованих лікарських засобів. 


\section{Summary}

Parfylo I. V. Problems of special knowledge application in the investigation of falsification and turnover of falsified medicines. - Article.

The article is devoted to the study of current problems of special knowledge application in the investigation of falsification and turnover of falsified medicines. It is substantiated that the most common forms of special knowledge application in the investigation of this category of criminal offenses are forensic, involvement of specialists during individual investigative (search), judicial actions or precautionary measures, as well as consultation and clarification of specialists. Particular attention is paid to the study of factors that determine the choice of a particular form of special knowledge application in the pre-trial investigation of criminal offenses. A critical analysis of the views of scientists on the definition of special knowledge in criminal proceedings, their specifics of application in pre-trial investigation and other issues that are debatable in criminalistics was performed.

It is noted that the most typical for such criminal offenses is the need to appoint pharmaceutical, pharmacological, forensic examinations and technical examination of documents. Given the presence in practice of significant difficulties with the choice of the above and related types of forensic examinations, the analysis and clarification of the subject and object of these examinations research was performed, a list of typical issues to be addressed by experts was proposed. The importance of the correct choice of one or another form of special knowledge application in the criminal offenses investigation is substantiated, as in practice forensic examinations are often appointed after several months of investigation, and often pre-trial investigation bodies are limited to reviewing departmental documentation of the State Service for Medicines and Drug Control. It is noted that the conclusions of the specialist and the involvement in the materials of criminal proceedings departmental documentation, on the basis of which medicines are recognized as falsified and withdrawn from legal turnover, can not replace a pharmaceutical examination. Given the specifics of this category of criminal offenses, important and significant is the need for further research in this area and additional study of problematic issues of special knowledge, in order to enhance and expand their capabilities, which can be an important step in improving the formation and implementation of forensic methods of falsification and turnover of falsified medicines investigation.

Key words: special knowledge, forms of special knowledge application, forensic, involvement of specialists, obtaining consultations and explanations of specialists, pharmaceutical examination, investigation of falsification and turnover of falsified medicines. 